\title{
A Socio-semiotic Study of Nicknaming among Undergraduates in a Nigerian University
}

\author{
Ibukun Filani and Omotosho Moses Melefa (Ibadan/Nsukka, Nigeria)
}

\begin{abstract}
The concept of name and naming is not just a tool for constructing identity; it is an important signification system in African cosmology. It is imbued with the people's perception of life and being. This explains why certain individuals who are discontented with their names either change them or adopt nicknames to reflect their sense of dignity, reinvented individuality and humanity. This paper explored nicknaming as a signification tool for identity reinvention from a socio-semiotic dimension. Data for the study was sampled purposively from students' halls of residence at the University of Ibadan and analysed using insights from socio-semiotic theory of sign. The use of irony in names was observed to be a common tool for reinvention, especially with those instances where the nicknames were given as derogatory labels to redesign the identities of the concerned personalities. It was observed also that others use nicknames to project a sense of reinvented self, especially in instances where the nicknames were the creations of the individuals concerned.
\end{abstract}

\section{$1 \quad$ Introduction}

The concept of name and naming is not just an identity marker; it is an important signification system in African cosmology. Therefore, the processes involved in giving a name to a child and the act of naming in the African society is taken with so much seriousness. This is because, as it is said in a Yoruba proverb, the name of a person tells much about the person. Since name is very important to Nigerians, it is not strange to find people changing their names and adopting new ones as a way of reinventing themselves. The act of changing names is common with converts who adopts new religions. Also, it is possible that a person might suddenly realise that his family name does not depict the faith (s)he is practising; therefore, a need arises for her/him to change the name. Another instance of changing of names among Nigerians is the adoption of what is commonly referred to as nicknames. This study analyses the adoption of nicknames among University of Ibadan undergraduates as a socio-semiotic system of signification for identity reinvention. It was observed that the signification derived from this socio-semiotic practice of nicknaming by the students studied followed defined and well-patterned morphological processes. This interesting linguistic practice deserves a linguistic investigation that will account for its structural processes of creation and its sociosymbolic functions within its context of use. Therefore, this study investigates nicknaming 
among students of the University of Ibadan, Nigeria as a socio-semiotic tool for identity reinvention.

It is important to give a working definition of names, and also, its possible types here. According to Harder (2008:I), names are "words signifying special and tangible things, either living, as in the case of a person or an animal, or inanimate, as in the case of a place or a concept." Since the focus is on humans, names are taken as referring expressions which are used to point out and identify human beings in their society. Harder (2008) further identified different kinds of human names. These include: personal names, which are used to designate both male and female in the human society; and first names, which are the names given to people at birth. According to Harder (2008), first name is also known variously as forename or Christian/Baptismal name among English speaking people. The last in his classification is last name which is also called family name or surname. The last name indicates a person's family background. It could depict the occupation of the person's lineage (Smith, Baker, Miller, Chapman etc.), location where such a person lives (e.g. Hill, Woods, Appleby etc.) and the person's parentage (names prefixed with Mac or Mc). He also identified nicknames and pseudonyms as categories under names. He notes further that nicknames could originate from recognition of a person's physical characteristics or verbal relationship or from association of ideas. On the other hand, a pseudonym is a name adopted by authors to conceal their true identity.

Within philosophical circles, there is a distinction between the description theory of what a name denotes and the causal theory of same. The former holds that, associated with each name as used by a group of speakers who believe and intend that they are using the name with the same denotation, is a description or set of descriptions taken from their beliefs which an item has to satisfy to be the bearer of the name. This description is used to explain the role of the name in existential, identity and opaque contexts. Kripke (1970), corroborated by Evans (1973), however attacked this view on the basis that it ignores the social character of naming. They rather argued for contextual considerations in the determination of the denotation properties of names. Although the arguments above are useful thoughts on names because of their consideration for context, the view of Mckay (1981) is considered more appropriate and directly relevant to this study because of his arguments for not only contextual considerations in the analysis of names but also for its connotative encapsulation, which was ignored by others.

In this study, the act of naming (christening or naming ceremony as it is widely known in Nigeria) is seen as traditional, since it is done in line with the customs of the parents of the child that is being named. On the other hand, nicknaming in this study is seen as a way of reinventing one's identity or that of others. The difference lies in the fact that in christening, the bearer is present but cannot make sense of her/ his situation, while in nicknaming, the bearer is fully aware of the situation. As such (s)he finds a means of remodelling the sign to produce the desired signification. Nicknames can be investigated from different fields like sociology, psychology, philosophy, linguistics (cf. Morgan/O'Neill/Harré 1979; Reid 1991; Bechar-Israeli 1995; Ecker 2011, Kripke, 1970; Evans, 1973; Mckay, 1980). A nickname is "a name we receive in addition to our legal name [which is] usually given to us by the people surrounding us" (cf. Bechar-Israel 1995). According to McDowell (1981: 1), "nicknaming 
practices are widely distributed, and everywhere contoured to the cultural matrices in which they operate." McDowell (1981) and Lakaw (2006) opine that the word nickname originates from the Middle English word- "an eke- name"- meaning another name. Thus, the etymology of the word nickname points to the fact that nicknames do not go with the naming convention (for instance, christening of a child) in the society where it is used. This is the reason why it is viewed as a socio-semiotic signification system for self-reformation or identity reinvention, and also as derogatory tags for reinventing the identity of others.

Names and nicknames have drawn the attention of scholars. Some of the studies on these phenomena looked at the traditional import of naming and nicknaming. Other scholars have also drawn attention to the significance of character naming in literary texts. An instance of naming in African literary text is found in Kuye by J. F. Odunjo. The hero of the Yoruba novel is Kuye, a Yoruba name which translates directly to 'Death pass over him'. In the novel, Kuye, an orphan, survived against all odds: poverty, sickness and wickedness melted on him by other characters. Thus the name Kuye was a pointer to the character traits of the hero. Oyeleye (1982: 137) has also commented on two characters: Okonkwo and Obierika in Things Fall Apart, asserting that their character traits and lifestyles are wrapped up in their names. In the same vein, Odebode (2005) carried out a pragma-sociolinguistic study of names and nicknames in Soyinka's Death and the King's Horseman. He identified the manner in which Soyinka used names to depict characters' linage, occupation, religion, social status etc. In all instances, the names depict the character traits and actions in the play. He established that "names in African Yoruba worldview are meaningful and that the immediate environment (of a text) subsumes many others in the wider environment. Names are indexes to characters and are part and parcel of African heritage which reflect social background, religious affiliation, occupation, gender and politics"(Odebode, 2005:211). Anglicising names is also common and has received the attention of scholars such as Knospe (2007) and Gorlach (2001).

Aboh (2011) also examines the naming practice adopted by Nigerian authors. He opines that names are linguistic windows to people and what they do. He asserts also that African writers use names to dismantle colonization and English domination by characterizing English names with negative meanings and portraying English named characters with negative social behaviour. Furthermore, to Aboh (2011), naming is a means of legitimizing the Nigerian writers' Nigerian identity since several writers would prefer to use Nigerian names for their characters. Based on what these writers do, naming practice becomes a political institution that expresses political ideology of individuals and their identity. In sum, Aboh (2011: 17) asserts that "...names form the core of our identity. Throughout human history, people have often used names to meet certain demands. Names are windows to a people and their culture. The names people bear link them to their past, culture and even their spirituality. The names people choose for their children and others reflect the relationship among name, identity and politics."

Some other works on names include: Babalola/Alaba (2003) who compiled a dictionary of Yoruba names; Sangotoro (2002) and Dimejesi (2007) looked at the structure of Yoruba and Igbo names respectively; Akinoso (1980) examined the sociolinguistic basis of Yoruba names; while Ajileye (1991) did a comparative study of English and Yoruba names etc. This 
current study differs from the ones listed above in the sense that the focus is on nicknames, paying particular attention to how they are utilised as socio-semiotic signification system for identity reinvention.

A closely related study to the present research is Ajileye/Ajileye (2003) which is a pragmasociolinguistic study of Yoruba nicknames. They drew attention to the meanings inherent in the nicknames that form the data for their analysis. They explored the stylistic significance of nicknames that results from the manner of construction, expression and perception of the names. The current study differs from theirs in the sense that it attempts to identify the patterns of nicknaming and see how nicknames function as a socio-semiotic signification system for identity reformation and reinvention among students of the University of Ibadan.

\section{Naming in African context}

Unlike what obtains in Europe, naming practices among Africans are a core aspect of their culture. They are shaped and deeply influenced by the cultural practices of the parents of the one to be named. This explains why the act of naming, either by parents or nicknaming, is taken seriously. For example, among the Yoruba of southwest Nigeria, the act of naming is done with fanfare (cf. Dáramolá/Jéjé 1967: 62; Òkédìjí et al. 1971: 68; Adéoyè 1972: 5, 1979: 256; Ekúndayo 1977: 56; Akínnàsò 1980: 277; Ikotun 2013: 66), depending on the social status and the financial capacity of the parents of the one to be named. Although there is controversy among scholars on the exact day for naming babies in Yoruba culture, for instance, Dáramolá and Jéjé (1967: 62), Òkédijí et al. (1971: 68f.) claim that "a male child is named on the 9th day, a female child is named on the 7th day and twins are named on the 8th day", and Adéoyè (1972: 5; 1979: 256), Ekúndayò (1977: 56), Akínnàsò (1980: 277), and Owólabí et al. (2009: 221), on the other hand, report that many Yorùbá people name their children on the 8th day as a result of Christian and Islamic influences; Ikotun (2013: 66) however argues that there are similarities in the findings of scholars on naming practices among the Yoruba of Nigeria. He (Ikotun 2013: 67) quotes Akínnàsò (1980: 279-283) who reports that Yorùbá personal names are drawn from the home context (HC) principle that is based on the Yorùbá proverb: Ilé ni à ń wò kí a tó so omo ní orúko ('The condition of the home determines a child's name'). Hence, socio-cultural conditions are considered before names are given in the African cosmology. This explains why names are laden with socioculturally valued pieces of information. This deep structure dimension to naming practices among Africans is not central to naming practices in the European worldview.

\section{Theoretical explications: The concept of sign}

A sign is anything that can be used to represent something. It can take the form of words, images, sounds, odours, acts, flavours, or objects (cf. Chandler 2002: 17). Saussure (1983: 66), an early theorist of signs, opines that it is made up of a "signifier" and a "signified". The signifier is the form that the sign takes, the material or physical form of the sign; while the signified is the concept to which the signifier refers.

Saussure's model of sign as having signifier and signified helps to create correlates with it as form or shape and content or meaning. Going by the subject of this study, the form is the morphological components and formations or style involved in the creation or generation of 
the nicknames. The form is thus made up of phonemes and morphemes employed in the creation of these nicknames and the rules involved in them.

Although Saussure's theorizations on the concept of sign are considered insightful, they are however deficient in the context of this study because of his concentration on formal systems at the expense of the social practices that shape language use. Although Saussure makes a distinction between langue and parole (language system and language use respectively), discourse was not adequately given attention in his theory. According to Chandler (2002: 83), "Saussure's focus on the language system rather than on its use meant that discourse was neglected within his framework." Since this study focuses on how nicknames function in contexts of use, it relies more on social semiotic approach to the study of sign. The approach emphasizes the functions and social uses of semiotic systems. It rests on some general assumptions about society and meaning (cf. Hodge/Kress, 1988).

In a social semiotics perspective, a sign in practical use functions in human interactions. According to Halliday $(1985,2004)$, the function of language in use is to create meaning. The meaning-making process cannot be separated from its social and cultural context. This is the point of departure for his social semiotics and functional grammar and purely structural views of Saussure. For structural semioticians systems (or structures) of sign and codes take precedence over "speakers and writers or other participants in semiotic activity as connected and interacting in a variety of ways in concrete social contexts" (cf. Hodge/Kress 1988: 1).

Social semioticians reject all forms of structural determinism. Whereas structural semioticians draw inspiration from the writings of Saussure, Levi-Strauss, and Mauss, social semioticians find inspiration in Peirce, Halliday, Bakhtin/Volosinov, Foucault, and in an oppositional reading of Saussure (cf. Gottdiener 1995; Hodge/Kress 1988; Vannini 2004). Social semiotics attributes meaning to power instead of merely attributing power to meaning (cf. Hodge/Kress 1988:2), and locates the origin of meaning within the field of semiosis, or in other words, within the process of context-bound and conflict-laden interpersonal interaction (cf. Vannini 2007). For social semiotics, much like for symbolic interactionism, meaning emerges out of the concerted intercourse of humans, each with differing motives, goals, and outlooks.

The field where semiosis occurs is known as the semiosic plane, and the connection that is thereby generated between referents and representations is known as the mimetic plane. Semiosic planes and mimetic planes rely on their recipients for them to function as intended (cf. Vannini 2007). In other words, meaning relies on the consequences of social action-a principle central to social semiotics as much as to pragmatism. In social semiotics, meaning, therefore, relies on use or practice whereas in structural semiotics meaning relies on the operation of structures that are as deep as the linguistic, physiological, psychological, and cultural unconscious that determine self, mind, and society (cf. Rochberg-Halton 1982).

Scholars like Vannini (2007) are of the opinion that the difference between structural semiotics and social semiotics in terms of structural determination is so important that it cannot be stressed enough. Structural semiotics is a formalist undertaking keen on a "mode of analysis that seeks principles and rules that account for a known pattern... [and for the] rules that govern conduct" (cf. Manning 1987: 29). Social semioticians view the conflict and struggle-laden process of semiosis (cf. Bakhtin 1984, [1965], 1981 [1975]; Volosinov 1973) 
and not deep structures, as the origin of meaning and therefore reject all forms of linguistic and structural determinism.

Within semiosis, one finds what Hodge and Kress (1988: 4) call logonomic systems. The word logonomic originates from the Greek logos (thought or system of thought, as well as the words used to signify that thought), and nomos (controlling mechanism). Hodge and Kress (1988:4) define a logonomic system as:

A set of rules prescribing the conditions for production and reception of meanings; which specify who can claim to initiate (produce, communicate) or know (receive, understand) meanings about what topics under what circumstances and with what modalities (how, when, why). Logonomic systems prescribe social semiotic behaviours at points of production and reception, so that we can distinguish between production regimes (rules constraining production) and reception regimes (rules constraining reception).

A logonomic system, therefore, is a social product "of organized social intercourse" (cf. Volosinov 1973: 21). People acting in concert with one another originate logonomic systems that order future transactions and make such transactions unambiguous. Of course, logonomic systems are not under democratic control. Agents with different degrees of logonomic power have more or less sway in the determination of the operation of new and existent logonomic systems (cf. Bakhtin, 1984 [1965], 1981 [1975]; Volosinov 1973). Because of the social origin and because of the directly and inevitably social and political consequences of the operation of rules contained in logonomic systems, social semiotics is thus invariably social in nature - in direct contrast with the irreducible origin of structures in structural semiotics. As Volosinov (1973: 21) puts it: "the form of signs is conditioned above all by the social organization of the participants involved and also by the immediate conditions of their interaction." Meaning is always negotiated in the semiotic process, never simply imposed inexorably from above by an omnipotent author through an absolute code.

Another source of differences between structural and social semiotics exists in relation to the nature of the sign. Even though all semioticians study signs, they are divided by a fundamental difference over the way they see signs. All structural semioticians tend to follow dyadic models of the sign, whereas social semioticians favour instead modified dyadic models or triadic models (cf. Vannini, 2007). Dyadic models generally draw inspiration from the work of Ferdinand de Saussure (1959). Saussure believed that signs are the unity of a mental concept (signified) and a symbolic vehicle used to express that concept to the self or to other people (signifier). Triadic models of the sign draw instead from the semiotic and pragmatic philosophy of Charles Sanders Peirce (1931), who, like all pragmatists, believed that meaning existed insofar as anything symbolic had practical consequences. For Peirce, therefore, the unity of a sign consisted of the relation amongst a referent (object), a sign vehicle used to express that referent (representamen), and the sense that someone made of the relation between the two (interpretant). He believes that without the interpretant the sign has no life, no consequences, and quite simply no meaning. It is the opinion of social semioticians that, because "signs may not be divorced from the concrete forms of social intercourse ... [and because they] cannot exist, as such, without it" (cf. Hodge and Kress 1988: 18), signs work in actuality as semiotic resources. Social semioticians prefer to refer to resources, rather than 
signs, following the lead of Halliday (1978:192), who argued that signifying systems were not a set of rules, but instead a "resource for making meanings".

Resources for making meanings include "the actions and artifacts we use to communicate, whether they are produced physiologically_with our vocal apparatus; with the muscles we use to create facial expressions, and gestures, etc. — or by means of technologies — with pen, ink and paper; with computer hardware and software; with fabrics, scissors and sewing machines, etc." (cf. Van Leeuwen, 2005: 3). Rather than a formal analysis of the operation of a code, therefore, social semioticians are interested in how resources "are used in specific historical, cultural and institutional contexts" (cf. Van Leeuwen 2005: 3). In contrast to the Saussurean structural semiotics, social semiotics tends instead to favour the study of culture, society, and politics as intrinsic to semiotics; other semiotic systems alongside verbal language; parole, the act of speaking, and concrete signifying practices in other codes; diachrony, time, history, process and change; the material nature of signs (cf. Hodge/Kress 1988: 18). So, the socio-functional and socio-symbolic dimensions of nicknames collected are the primary concerns of this study, even though the structural processes of the creations will also be analysed.

In explicating the form of the nicknames which are the subject of this study, the formal processes of their creations followed two basic approaches in the study of the morphology of words. These approaches are: word and paradigm, and item and process. The basis for combining the two is that no one model of morphological analysis can serve all purposes when it comes to analysis of words components. Therefore, there is the need to combine the relevant features for an analysis in both of them (cf. Malmkjear 1995: 364).

The word paradigm approach holds that the word is central and fundamental unit of grammar and it establishes the word as an independent and stable unit in language. In this approach, word forms that share a common base are grouped into paradigms. Paradigm categories include inflectional markers such as tense, number, persons etc. The use of this approach to set out inflectional morphemes also makes it applicable for derivational morphemes (cf. Malmkjear 1995: 363). This approach portrays nicknames as words (a unit of grammar that can further be analysed into its components- morphemes).

After identifying the component morphemes of these nicknames, the item process is used to uncover the morphological processes involved in the creation of the nicknames since according to Malmkjear (1995: 363), "it relates items to one another by reference to morphological processes". These processes include affixation, blending, compounding, clipping, backformation etc. This approach sees the morpheme and not the words as the basic unit of grammar. Thus, this will be used to identify the base of each newly created nickname. In sum, for the purpose of this study, these two approaches are seen as complimentary rather than opposing.

The second part of this study, which is the concept or meaning to which the sign (nicknames) refers, is read following socio-functional approach of social semiotics described above. The form of the nicknames is not enough in itself for it to be called a sign; rather, it is the contextual interpretation of the form, which is the meaning of the sign that helps to identify it as a sign. So, if meanings cannot be invoked from signs, then they cannot be seen as signs. Their meanings are contextual, that is, they are identified as meaningful only in the situations 
where they occur. In this regard, the social functions the nicknames perform are identified through their indexical links with the signs in which they are represented. In application to nicknames, apart from functioning as means of identification in the context where these are created and used, it was observed that they also perform the following functions: 1) indicate a behavioural pattern e.g. Gallas, the name of a professional footballer. The bearer of the nickname is so labelled because he plays football like Gallas, a professional footballer, 2) inform about a particular trait or character or ability, for instance, Plato (name of a philosopher) for a student who is highly eloquent and outspoken, 3) hide identity or traits especially in instances where they are derogatory biases and negative interpretations or meaning, for instance, sisi kamo (the bearer though a male is believed to behave like females). These functions will be fully illustrated and explained in the analysis.

It is important to state that a sign has denotation and also, connotation. Denotation refers to the dictionary meaning of a word, while connotation refers to additional meanings resulting from the context in which the sign is used (cf. Martin/Ringham, 2000: 42f. and 49; Chandler 2002: 142). Connotative meaning of words helps to generate new contextual meaning for signs which has nothing to do with the denotative meaning of the sign or could even be an extension of the denotative meaning. According to Chandler (2002: 140), the term connotation is used to refer to the socio-cultural and "personal" associations (ideological, emotional, etc.) of the sign. He notes also that signs are more "polysemic" - more open to interpretation - in their connotations than their denotations. Although the Saussurean theory of sign focused more on denotation at the expense of connotation (cf. Barthes 1957), however, a socio-semiotic model bridges such a gap and helps one to explore this dimension to explicate the functioning of nicknames in this study.

Following the socio-semiotic approach to the sign, in this study, the following propositions are made: nicknames are taken as indexical modes of signs which indicate something in or for the bearer (referent). If they are taken as indexical signs, then they would be seen as linking the nicknames to a social reality or a social practice which the bearers stand for or are made to represent. Such things include identity, behaviour, action, character, skill or ability, body feature etc. Also, if there is a common bias or social tag that is derogatory about a name or culture, a student may use a nickname to cover such or anglicise any of her/his name.

\section{$4 \quad$ Methodology}

The nicknames used in this study were collected from student hostels at the University of Ibadan. The researchers observed students interactions in their halls of residence and other environments like the sporting fields, the eateries and the common rooms in the students hostels. It was from these interactions that the researchers observed the peculiarity of the nicknames that the students use to call one another. The researchers did not depend on their observations alone; some occupants of each hall of residence were also employed as research assistants who helped to collect the common nicknames used in their halls of residence. They were told to write down the common nicknames used in their halls of residence, their meanings and the reason or context that birthed such nicknames. In this manner, the research assistants were able to write down the common nicknames in the undergraduate halls of 
residence and the patterns of forming them. It was observed that the methods used for creating the nicknames collected were not arbitrary.

The ten students, who wrote down the nicknames after they heard their colleagues used them in their interactions in the halls of residence, also engaged their users to explain the meaning, the situations that gave rise to the nicknames and their contexts of use. In all, the study is limited to six undergraduate halls of residence (four male and two female) of the University of Ibadan. More male hostels were used because female hostels in the university are fewer than male hostels. In the handwritten lists that were retrieved from the research assistants, there were a number of repeated nicknames, as well as patterns of forming the nicknames. These findings are not unconnected to the fact that the occupants of the hostels have the same cultural background, which could be any of the numerous Nigerian cultures, especially, one of the major tribes of the country. The number of nicknames turned in from each of the assistants' ranges from as low as five nicknames to as much as eighty-two. One hundred and twenty-two nicknames were collected from the female halls of residence while one hundred and seventy-four were collected from the male halls of residence. In all, two hundred and ninety-six nicknames were collected, from which selections were made for analysis.

The students communicate in basically three languages: English (official and lingua franca of Nigeria), Yorùbá (the language of the immediate community where the university is situated) and Nigerian Pidgin. In instances where students do not understand Yorùbá, Nigerian Pidgin or English is used. It should be noted that Nigeria is a multilingual country with well over 400 languages and cultures (cf. Adegbija 1994). From observations, the peculiarity of the context where these nicknames were collected is that it is a multicultural context that is made up of several Nigerian cultures and even the English language. It should be noted that the bearers of the nicknames already have their names but decided to adopt different nicknames which are used in informal situations. Also, in some instances the nicknames were given to the bearers by their hostel colleagues based on certain perceived features.

\section{Data presentation and analysis}

The data for this study is presented below and analysed. The analysis of nicknames used among students studied is divided into two segments. The first segment deals with the structure of the signs, while the second deals with their functions. In the first segment, the structural processes which were used in the production of the nicknames were explored following word formation processes. In the second part of the analysis, the socio-functional meanings of the nicknames were accounted for by making reference to the socio-cultural clues that gave rise to their creation.

\subsection{Data presentation}

\begin{tabular}{|l|l|l|l|l|l|l|l|}
\hline $\begin{array}{l}\text { Role- } \\
\text { modelled } \\
\text { nicknames }\end{array}$ & $\begin{array}{l}\text { Anglicised } \\
\text { nicknames }\end{array}$ & $\begin{array}{l}\text { Association } \\
\text { nicknames }\end{array}$ & $\begin{array}{l}\text { Ironic } \\
\text { nicknames }\end{array}$ & $\begin{array}{l}\text { Sexist } \\
\text { nicknames }\end{array}$ & $\begin{array}{l}\text { Personal } \\
\text { features } \\
\text { nicknames }\end{array}$ & Total \\
\hline \hline 25 & & 130 & 23 & 3 & 8 & 107 & 296 \\
\hline
\end{tabular}

Table 1: Data summary 
From the table above, anglicised nicknames have the highest number, followed by personal features nicknames while other categories are fewer in number. The students' propensity for using anglicised nicknames shows their desire to showcase their sense of modernity. The adoption of anglicised nicknames is deployed by the students as a socio-semiotic tool to subtly reject the identity that is captured in the names given to them by their parents. It presents them with the tool for self-reformation and reinvention.

\begin{tabular}{|l|l|}
\hline Nickname & Contextual Meaning \\
\hline Gallas & Indicating a student who plays soccer just as the French footballer- Galla \\
\hline Dr Dre & The bearer is nicknamed after the hip-hop star Dr Dre \\
\hline Usher & The bearer is nicknamed after the R and B singer Usher \\
\hline Plato & $\begin{array}{l}\text { The bearer is nicknamed after Plato, an ancient Greek philosopher to } \\
\text { indicate a student who is very eloquent }\end{array}$ \\
\hline Carragher & Indicating a student who plays soccer like the English footballer- Carrager \\
\hline Clinton & $\begin{array}{l}\text { The bearer adopted the name "Clinton"- the former US president, for the } \\
\text { students' union electioneering purposes. }\end{array}$ \\
\hline
\end{tabular}

Table 2: Role-modelled Nicknames

\begin{tabular}{|l|l|}
\hline Nickname & Contextual Meaning \\
\hline Flakky & $\begin{array}{l}\text { From the bearer's first name "Folake": indicates student's perception of } \\
\text { modernity }\end{array}$ \\
\hline Lakeside & $\begin{array}{l}\text { From the bearer's first name "Lakan": indicates student's perception of } \\
\text { modernity }\end{array}$ \\
\hline Sunky & $\begin{array}{l}\text { From the bearer's first name- "Sunkanmi": indicates student's perception of } \\
\text { modernity }\end{array}$ \\
\hline Ty & $\begin{array}{l}\text { From the bearer's first name- "Tayo": indicates student's perception of } \\
\text { modernity }\end{array}$ \\
\hline FM & $\begin{array}{l}\text { From the bearer's first name- "Femi": indicates student's perception of } \\
\text { modernity }\end{array}$ \\
\hline Dotman & $\begin{array}{l}\text { from the bearer's first name - "Dotun": indicates student's perception of } \\
\text { modernity }\end{array}$ \\
\hline
\end{tabular}

Table 3: Anglicised Nicknames 


\begin{tabular}{|l|l|}
\hline Nickname & Contextual Meaning \\
\hline Taobarca & $\begin{array}{l}\text { "Barca" is the unofficial name of Barcelona Football club while "Tao" is } \\
\text { clipped from the bearer's first name. The compound indicates the bearer's } \\
\text { favourite European football club. }\end{array}$ \\
\hline Omo jesu & $\begin{array}{l}\text { The compound translates to Jesus' child. Here, it indicates that the bearer is a } \\
\text { fanatical believer in Jesus. }\end{array}$ \\
\hline Afa Sule & $\begin{array}{l}\text { "Afa" is the Yoruba word for Islamic scholar while "sule" is the bearer's first } \\
\text { name. The nickname indicates the bearer's religious beliefs }\end{array}$ \\
\hline Alovet & $\begin{array}{l}\text { The nickname is made up of two words: "alo" clipped from the bearer's first } \\
\text { name "alonge" and "vet"- clipped from the bearer's field of study, Veterinary. } \\
\text { The nickname not only indicates the bearer, but it also indicates the bearer field } \\
\text { of study. }\end{array}$ \\
\hline Orisa & $\begin{array}{l}\text { "Orisa" is the Yoruba word for gods. Here, it is used to refer to a student who } \\
\text { has a twin. It indicates the Yoruba belief that twins have specific gods. }\end{array}$ \\
\hline
\end{tabular}

Table 4: Association Nicknames

\begin{tabular}{|l|l|}
\hline Nickname & Contextual Meaning \\
\hline Mount zion & $\begin{array}{l}\text { An allusion to biblical mount zion, where it is said there will be holiness and } \\
\text { deliverance. However, here, the idea of a mountain as a large amount of } \\
\text { something is used in deriving this nickname. Here it describes a lady with big } \\
\text { buttocks. }\end{array}$ \\
\hline Sisí kamo & $\begin{array}{l}\text { "Sisí" is the Yoruba word for young lady but it is used here to describe a male } \\
\text { student who behaves like a lady. }\end{array}$ \\
\hline İrókò & A tall tree. Here it is used to describe a student who is very short. \\
\hline
\end{tabular}

Table 5: Ironic Nicknames

\begin{tabular}{|l|l|}
\hline Nickname & Contextual Meaning \\
\hline Sirdick & $\begin{array}{l}\text { "Sir" is a politeness marker in English, while "dick" is the colloquial term for } \\
\text { penis. The compound describes a student who is said to have big penis. }\end{array}$ \\
\hline Mount zion & It describes a lady with big buttocks \\
\hline Occulumotor & It describes a lady with big buttocks \\
\hline Kinkyqueen & It describes a female who acts provocatively \\
\hline
\end{tabular}

Table 6: Sexist Nicknames

\begin{tabular}{|l|l|}
\hline Nickname & Contextual Meaning \\
\hline Atom & For a student with a small physique \\
\hline Tall man & For a student with great height \\
\hline White angel & $\begin{array}{l}\text { The name indicates the bearer's gentle and peaceful manner of dealing with } \\
\text { her peers. }\end{array}$ \\
\hline Kekere & $\begin{array}{l}\text { Kekere is an adjective in Yoruba which translates to small. It is used here to } \\
\text { indicate the bearer's smallish physique }\end{array}$ \\
\hline Epo dòdò & "Epo" is the Yoruba word for oil while " dòdò" is the Yoruba word for \\
\hline
\end{tabular}




\begin{tabular}{|l|l|}
\hline & $\begin{array}{l}\text { plantain. The compound here refers to palm oil, and in the context of use, it } \\
\text { denotes that the bearer is very light in complexion. The nickname "dòdò" must } \\
\text { have been adopted because "epo" here refers to palm oil, which colour is red. }\end{array}$ \\
\hline Ak short & $\begin{array}{l}\text { AK is an acronym from 'Akin' the bearer's first name while short here is used } \\
\text { to connote the bearer's height. }\end{array}$ \\
\hline Methuselah & $\begin{array}{l}\text { Methuselah is the oldest man in the bible. He died at the age of } 969 \text { years old. } \\
\text { Here, it is used as a nickname for a student who seems too old for his class. }\end{array}$ \\
\hline
\end{tabular}

\section{Table 7: Personal Feature Nicknames}

\subsection{Structural analysis}

In what follows, each nickname is taken as a word, that is, a linguistic sign that is created through a morphological process. Thus, the processes followed for the production of the nicknames collected for this study are explained:

a) Coinage: This is a process whereby a language user deliberately creates a new word or inadvertently uses a word in a particular context for effective communication. In the situation studied, there were instances where the students deliberately created names that were previously not existing and purposively attached meaning to them. In several instances, the meaning is got by ostensive definitions. There were also instances where already existing lexical items acquire new meanings, that is, they were not names of persons but were used as nicknames for the bearers. Examples are:

Locosuma (which is coined for the bearer who, as a female student, wears too much make up that make her look unattractive; its creation is probably inspired by the students' knowledge of Japanese sumo wrestlers, Yokozuma), Occulemotor (the bearer who is a female student is said to have big buttocks; morphologically, the word is made up of occule+motor, the first morpheme is got from a popular Nigerian exclamatory form, o cool, which is used in the south-western part of the country to show attraction, although this was recreated by the students contextually, while the second is an English word used by the students to express the idea that the big buttocks is an engine), Sisí kamo (sisi is the Yoruba word for young lady while kamo is a deliberate coinage. The bearer who is a male student is said to behave like a lady), Header (for a student who is believed to be too old for his class), Ironman (the bearer is said to be very hard working), Easybones (the bearer is said to be trouble-free and easy going), İrókò (Ironic name for a short person. İrókò is the Yoruba name for tall a species of hard word found in the rainforests of western Nigeria).

b) Compounding: This is a process where by two words that have independent existences are combined to form a single word (Katamba, 1993 and Malmkjear, 1995). Instances of compounding in our corpus include:

Lakeside (lake+side, from Láken which is the bearer's real name), Slim shaddy (from the bearer's physical features. The bearer is dark in complexion and slim). It connects, intertextually, to Eminem's The Real Slim Shady, though with a different contextual function, Lolly pop (from the bearer's first name which is Lolá), Cool sholly (from the bearer's first name- sholá; also the bearer is perceived to be usually relaxed), Kinky queen (anglicised version of the bearer's first name, Kíkélomo; used for a female who dresses or acts in sexually provocative ways), Demo pumping (demo is from the bearer's first name, Démólá used to 
show that the bearer is a 'happening' person or always everywhere), Jayman (jay+man, the Jay is from the bearer's first name, Jámíù).

c) Neologism: This is a process that involves semantic shift. It involves giving words new meanings or changing the meaning of words. Also, it involves instances where new words are created and are given meanings. The examples under coinages also fall under neologism. Other instances of neologism in the corpus include:

i. Instances where names of renowned person is given to a student because the student has similar traits with the original bearer of the name. When this is done, the meaning of such name, if we go by referential theory of meaning, changes. Examples found include: Plato (the philosopher), Anelka (a footballer), Obama (U.S. president), Gallas (a footballer), Okurame (here the student is nicknamed after a lecturer, whom the student mimics) etc.

ii. Instances where names of socio-cultural items such as place, food, clothing etc. are given to a student because of the student's regular use of such items. Examples are: Mount Zion (an allusion to the biblical location, in this context, a place where Christian students pray), indomie (a popular brand of noodles in Nigeria), gala (a popular brand of sausage roll in Nigeria), vespa (a brand of motor bike) etc.

iii. Instances where a student is given a name due to perceived behavioural or physical features. Examples of this include: Negro (used to refer to the bearer's colour, reference to black stereotype in America), kékére (translation-small), irókò (common specie of a tree that grows very tall, its use here is ironic since it is used for a short person), atom (the bearer has the smallest stature among his colleagues), emergency (the bearer is said to be anxious always), conscious (the bearer is said to be conscious always), header (the bearer is perceived to be too old for his class) etc.

d) Clipping: This is a process that involves the deletion of initial morphemes or final word segments (Malmkjear, 1995). Words formed through clipping usually retain the meaning of the words from which they are formed. Examples are:

Sege from Ségun, Damy from Dámilólá, Eni from Eniólá, Olait from Oláiítán, Sunky from Súkànmí, Bamdel from Bámidélé, Pato from Patrick, Flakky from Foláké, Nas from Násírù, Leo from Leonard.

e) Blending: This is a word formation process whereby elements of two different words are combined to form a new word. It is usually accomplished by taking the beginning of a word and combining it with the ending of another word. Instances of blending in the corpus include:

Alovet from the bearer's name Alón'gé and his department Veterinary, Clazyone from the bearer's behaviour which is believed to be Classical and the numeral pronoun One, Karbey from the bearer's real names- Kareem and Abáyòmí, Taobarca from the bearer's first nameTaofeek and his favourite football club Barcelona, Bellodinho from the bearer's first nameBéllò and his favourite footballer Ronaldinho, Jegbol from the bearer's first and last names- 
Bola and Jégédé respectively, Dunnelle from the bearer's first name Iyádùnùnni and the French feminine pronoun elle.

f) Back-formation: This occurs when a long word is shortened by removing parts of the word that are perceived to be morphemes (Malmkjear 1995). Examples of such in our corpus are quite few but are still worthy of mention. They include:

Limsy from Halima, Wendy from Olawande, Lammy from Olamide.

g) Abbronym: This is a blend of abbreviation and acronym. Instead of forming a new word by calling the initial letters of words, they act as the name of an entity as a single word e.g. UNESCO, NATO, the initial letters are pronounced independently. In sum, the names of letters are pronounced instead of forming words with the initial letters of the phrases. Although, names are not seen as phrases, but the underlying principles that follow abbronyms are also applied here. This is why the process is classified as abbronym. Examples are:

A.B. from Abiódún, F.M from Fémi, B.J. from Bóláji, C.J. from Chijioke, A.K from Akin, M.O.R from Michael Olúwáségun Rájí, N.G from Ngozi, K.C. from Kelechi, M.C. from Maduagwu Chwukwudi.

h) Refashioning: The term refashioning is used to refer to instances where a name is spelt in an inverse manner and then pronounced in that order. That is, beginning with its last letter as the first letter and the first letter as the last one. Instances of refashioning are also very minimal in the corpus used for this study. The ones found are as follows:

Edmy from imde, which is got through back-formation from Olamide; Sacrod from Dorcas.

Although it is difficult to assign meaning to the component parts of the newly created nicknames (that is, break them into morphemes and give their specific meanings), they are formed from established processes of forming new words. From the above, it can be deduced that the nicknames are not randomly done but patterned creations which reveal the competence of these language users in the languages they speak. Even though it is difficult to deduce the meaning of the morphemes used in the formation of these words, the creations show learnt and patterned methods of word formation. The analysis reveals that the students only bring to fore the tacit knowledge of the languages they speak in the formation of the nicknames since these processes are found in the languages they speak, most especially English.

\subsection{Socio-functional analysis}

The social function or interpretation of sign is assigned to it by the users of the sign by convention, through repeated use and it is transferred from one generation to another. It is also possible for signs to have restricted use, that is, its function or interpretation may not cut across all spectrum of the society. In this second instance, it only stands in particular way representing a particular meaning to someone in some way. Therefore, in this section, an attempt is made to see what functions these nicknames perform in the context of a Nigerian university. Attempt is made to categorise the nicknames under the socio-symbolic functions they appear to perform through the way they are formed. These are seen thus: 
a) Role modelled nicknames: These are names of prominent social actors that are now recreated as nicknames of students. Social actors, as used here, are popular personalities in the society such as artistes, sportsmen, scholars, politicians etc. Therefore, nicknames that fall under these categories are names of such people, dead or alive, in the society. The criteria that determine if a social actor's name will be used as a nickname for students include: the popularity of the social actor among the students, the acceptance of the social actor among the students and existence of a physical or behavioural feature that the social actor is commonly known to share with the student that will be given the social actor's name as a nickname. It seems that the last factor is the main determining factor. Examples of nicknames under this category in our corpus include:

- Plato (name of a philosopher) for a student who is highly eloquent and outspoken

- Gallas (a French footballer) for a student who plays soccer like him

- Bonfere (a football coach) for a student who is passionate about and knows so much about football

- Gerald (an English footballer) for a student who plays football like him)

Bellodinho (bèllò+ Ronaldinho(a Brazilian footballer)) for a student that plays football very well.

In mapping out the social function of these names, the first two as examples are used thus:

Plato is an ancient philosopher who is known to be eloquent; the bearer too is seen to be eloquent like Plato; thus he is nicknamed Plato. In an interview with the research assistants that helped to gather this data, it was revealed by the students that the nickname comes with a high sense of nobility, so, it is only those with proven oratorical prowess that are so nicknamed by the students. The social practice therefore provides the students with the opportunity not only to celebrate Plato's oratory but also to encourage students to develop oratorical abilities, since they stand the chance of being celebrated like the renowned philosopher in the context of the students' universe. So, Plato, in the community of the students, is not just a nickname, but a socio-symbolic sign that delineates oratorical mastery. Within this socio-cultural context, therefore, the nickname is indexically connected to and represents oratorical excellence. In the same vein, Gallas is a professional footballer. The bearer too plays football like Gallas, a professional footballer. The bearer is thus nicknamed Gallas.

Bonfere Joe was a coach of Nigeria's Super Eagles - Nigeria's senior national football team. Under his tutelage, the team had excellent outings and performed so well in international competitions. So, the indexical sign "Bonfere" was semiotically deployed by the students to reconstruct the era of excellence that he stands for in Nigeria's football history. The sociosymbolism of Bonfere Joe's excellent coaching skills is what the nickname 'Bonfere' is reconfigured to capture in the bearer.

The idea that is captured in these role-modelled nicknames is that since they (the nicknamed students) share a common attribute with the original owners of the name, they too could be as great as the social actors that bear the names, especially in situations where the nicknames are the creations of the individuals concerned. The idea of social identification with the 
personalities of the celebrities that bear the names is also implicated in this category of nicknames. They also seem to be telling their colleagues that in order to know what they do best, their colleagues only need to examine the social significations of their nicknames closely and what they do best will be realised without being informed.

b) Anglicised nicknames: Anglicism is commonly defined as the use of English expressions or linguistic mannerism in other languages (cf. Knospe, 2007; Gorlach, 2001). Gorlach (2001) particularly observes that it is the use of any word that is English in form (spelling, pronunciation, morphology, or at least one of the three) in vocabulary of another language and it is accepted in the receptor language. From the corpus, it was observed that anglicised nicknames took the largest chunk of the data collected. In most cases, it was observed that the students carry out the following permutations on their real name to form their nicknames:

1. Use English pronunciation to articulate names from their first language. There are instances where the tones on the names were replaced by stress e.g. sholee from sholá pronounced as sho'lee; Jegbol from Jégédé Bola (literally means given birth to wealth) pronounced as Jeg'bol, Dammy from Dámilólá (Blessed with wealth) pronounced as 'Dammy.

2. Use English spelling to spell names from their first language. e.g Jay from Juliet, eyebeekay for ibk which is from İbúkùn (Blessing), hibee for Ibrahim etc.

3. Combining English morphemes with their names or using only English morphemes to form the nicknames e.g. D-one from Dayó which literally means has become joy, kunzzy from Kúnlé means full the house, Ebony for someone that is dark in complexion and pretty, Dammy from Dámilólá, Lakeside from Lèkan, which literally means has increased by one, Flakky from Foláké which literally means cared for with wealth, Slim-Shady for someone who bears Shadé and is slim etc. Shadé literally means used to crown.

Obviously, the motivation for anglicising names is to depict modernity and civilisation. It seems that the students are saying, with their anglicised names, that the names from their languages cum culture do not capture their sense of modernity and civilization and of course are too local to be borne in the context of the university, and by extension in the modern world. Therefore, in order to keep contact with their tradition and still prove that they are very modern, most of their names are anglicised and reinvested with a sense of modernity. In a bid to affirm this assertion, when asked, some of the students noted that the practice was just to make their names sound and look trendy. Thus, the anglicised nicknames reflect the students' perceived sense of modernity. The practice of anglicising their names reveals a protestant attitude towards the old order in their culture. This kind of attitude seems to signify a call for cultural rebirth and reinvention.

c) Association nicknames: These are names that are used to signify the bearer's association with social organisations such as religious bodies and sport clubs. With these nicknames, the students try to inform their society that they belong to a particular religion or that they are enthusiastic admirers of a sporting club. The students, apart from names that suggest this, also depict their association through their mode of dressing. For instance, they could wear the jersey of their favourite sport club; students called pastors are usually seen dressed neatly 
with shirt tucked in while those called alfa are usually dressed in long gowns or short trousers. Examples of nicknames in this category are:

- Gunners: the unofficial name of an English football club- Arsenal Football Club

- Alfa: for a male Muslim student who is passionate about his religion

- Pastor: for a male Christian student who is passionate about his religion

- Taobarc: a compound from Taofeek and Barcelona. In this instance, it is used to signal that the bearer is a fan of Barcelona football club.

Although the religious nicknames function connotatively within the domain of the students' religious life, while the football nicknames were creative products of the students' football experience, they both function as association nicknames because their functioning is in the associative value of their indexical representations of aspects of the students' social experience. So, their similarity is in the fact of their related social associations and function within the context of their use. A student is nicknamed "pastor" because he/she is seen to be religious and packages himself/herself with a high sense of reverence. The same thing goes for the indexical dressing of a student who is clad in long gowns or jumpy trousers. The indexical link between the students' appearance and conduct and the socio-cultural context are the platforms upon which such social significations and associations are anchored. Taobarc, for example, socio-symbolically connects the bearer to Barcelona football club in the context of the students' social experience; just the same way pastor connects to their religious experience.

d) Ironic nicknames: These are those that have ironic undertones. As noted by Chandler (2002), an ironic sign means the opposite of its literal signification. The nicknames in this category were deployed as opposites of their structural meanings. These include: Sisi kamo (the bearer though a male is believed to behave like females), İókó (a tall tree) is used as a nickname for a short person. Sisi, which is the Yoruba common noun for a young charming lady, is adopted and deployed to signify feminine attributes that are seen in the bearer. Though the bearer is male, this nickname is used to undermine the bearer's sense of masculinity. Its ironic undertone also comes with a derogatory implication. With this category of nicknames, the students try to ride on their seemingly harmless surface structural composition to conceal their socio-symbolic meanings.

e) Sexist nicknames: these are nicknames that used with sexist intentions. They include: locosuma (the bearer who is a female wears too much make up that make her look unattractive), occulemotor (the bearer who is a female student is said to have big buttocks), kinky queen (anglicised version of the bearer's first name, Kikélomo; used for a female who dresses or acts in sexually provocative ways), dupsy damsel (dupsy, an anglicised form the bearer's Yoruba name, Dúpé and English 'damsel' for someone who acts and walks in sexually provocative ways), mount Zion (a popular place of worship on campus), which alludes to the Biblical Mount Zion, but used contextually to refer to a lady who has big buttocks or hips. Sirdick is also used by the students to refer to a male student who has big penis. Even though there is nothing in the formal properties of the nickname to suggest this kind of reading, the students affirmed, when interviewed, that they use it to nickname someone whose penis is big. It is structurally made up of two words, "sir" and "dick". "Sir" is a polite expression for 
addressing a male and "dick" is a slangy expression for penis. Within Nigeria's socio-cultural context, when 'sir' is used, it is imbued with a connotation of the speaker's perceived sense of bigness of the addressee. Obviously, the students exploited this socio-cultural resource to articulate the sense of the bearer's big penis in the nickname.

f) Personal feature nicknames: These are nicknames that are used to signal either a physical or behavioural characteristic in the bearer. Examples are: Ebony (for someone dark in complexion); Bororo (name of the cattle rearing tribe in Nigeria who are known for their light complexion, for someone that is light in complexion); T-black (a compound from Túndé and black, for someone who is dark in complexion); Kékeré (Yoruba word for small, for someone who is quite short); Atom (the smallest indivisible part of an element for someone who is the smallest in his class); Conscious (for someone who is always very careful in his dealings); and Bluekid (for someone who is said to always wear blue contact lens). The students leveraged heavily on their socio-cultural experiences to articulate their reconstructed identities in the nicknames. So, meanings cannot be adduced to the nicknames without contextual considerations.

\subsection{Implications of the students' nicknaming practices for identity construction}

Social identity theorists like Tajfel (1979) and Turner (1985, 1987) have provided the framework for the articulation of social identity and group interaction. They argue that group behaviour and intergroup relations provide the tool to understand the connection between individuals and group identification. They also contend that because people define themselves in terms of their social group membership and enact roles as part of their acceptance of the normative expectations of in-group members, the concept of role is subsumed under the concept of group (Turner et al. 1994). This, no doubt, can be utilised to explain how the students studied have adopted nicknaming as a template to forge a youth culture that will act as a melting point for the student community. As Turner (1987) notes, a particular identity becomes activated as a function of the interaction between the characteristics of the perceiver and the situation. So, the campus situation provides the students with a common front to interact and to create group and individual identity tags.

The nicknaming practices of the students have some implications for identity construction both at the collective and individual planes, since the ideas projected in their nicknaming practices are those of reinvented/reformed identity of self or others. Since identity studies have been relocated to the collective (cf. Cerulo, 1997: 386; Appiah/Gates, 1995: 1; Faleye/Adegoju, 2012), and scholars are now engaging the mechanics for creating, maintaining and changing distinctions, therefore, the claim that one could have multiple identities and switch between them in different contexts is valid, especially in the context of this study. The subjects of this study have already been christened by their parents and such names are borne by them in official documents and within the home context. In addition to the names they were given by their parents, they adopt or are given nicknames by their colleagues, which often capture their sense of a redefined individuality. So, we are presented with a situation whereby there is double or multiple identities, with each used in different contexts. In the home contexts for example, Taofeek will retain his parent-given identity as Taofeek, but would become or switch to Taobarc (Taofeek+Barcelona) in the context of the 
university among his friends and colleagues. So, there is double consciousness or identity embedded in a personality, a sense of reconstructed or redefined self. Some of the students not only answer to these nicknames whenever they are called, they also wear vests and t-shirts that bear such inscriptions. These are socio-semiotic strategies for using the nicknames. As far as they are concerned, the new identities captured in the nicknames are such that must be made prominent. In fact, the nicknames enjoy more social acceptability among the students than their parents-given names. They also engender a greater sense of popularity for the bearers among their colleagues. The attention of the researchers was actually drawn to this socio-semiotic practice in classrooms where such nicknames were used by the students and also inscribed on their vests and t-shirts. In their halls of residence, such were also noticed to be common inscriptions on the walls and other public places.

At the collective plane, nicknaming is utilised by the students as a signification system to reconstruct their identities. It presents them with veritable tool to rearticulate certain traits in them that were not captured in the signified of their parent-given names. So, the sign is remodelled in the nicknames to project their current identities. The reinvested signs (nicknames) are imbued with ingredients to redirect what they conceive as inadequate portrayal of their personality to the newly reconstructed identity. This sense accounts for why the name Béllò at the individual plane, which does not capture the ability of the bearer to play football well, is remodelled as Bellodinho to reconstruct the identity of an individual who is a skilful footballer. Since the self is defined primarily by virtue of its membership of, or identification with a particular group or groups (cf. Benwell/Stokoe, 2006), the generation of the new identities of the students that are embodied in the nicknames stems from their sense of collective or group identity that is perpetuated within the university context. So, the group identity gives rise to the individual identity that is signified in the nicknames of the students. The collective identity upon which the nicknaming practice is hinged symbolises the evolution of a youth subculture that reflects the current sweeping wave of social identity mobilisation.

\section{$6 \quad$ Findings and Conclusion}

The use of irony in nicknames is observed as a common tool for reinventing the identity/personality of others, especially with those instances where the nicknames are given as a derogatory label to rebrand a personality. Ironical statements are commonly seen as utterances used to express the opposite of their literal meaning. In this study, it was observed that the students, in a bid to avoid vulgar words and keep within the limit of politeness, use names that have positive denotations while they mean the opposite. What they connotatively mean with such names are the negative connotations that could be drawn from such names. Examples of such names are iroko and sisi kamo.

Ìrókò is the Yoruba word for a tree that grows very tall and is used for timber. The tree is pervasive in the rain forest region of Nigeria. İrókò as a nickname, as was found in this study, is used for a very short person. Likewise, sisi kamo is used to refer to male student who behaves like a female. Sexually provocative nicknames are also used by the students as tools to reinvent the identity/personalities of others. A few nicknames were found that are aligned to sex. Examples are: Sirdick (for a male student who is said to have a big penis) dick is a 
slang expression for penis, bottom power and mount Zion (for female students who are said to have big buttocks). Mount Zion as used by the students is an allusion to the biblical Mount Zion. It is said that there shall be holiness on mount Zion and the people of Israel shall possess their possession on the mountain. In the student's vocabulary, Mount Zion is a popular place where Christian students meet to pray and have fellowship. However, from this study, it was discovered that it was used as nickname for a female student who is said to have big buttocks or hips.

The impact of the English language on the nation's culture and indigenous languages is foregrounded in anglicised nicknames. The impact of the English language on Nigerian languages, cultures and traditions cannot be denied since English as well as their culture is reflected in the anglicised nicknames. The practice of anglicising names also challenges and changes Nigerian social norms as can be seen in the nicknames. Anglicism is also a reflection of what the students take as modernity. The anglicised nicknames are reflections of creativity in the students which enables them to keep touch with their first cultures which are embodied in Nigerian languages and at the same time a new one which is represented by English. They show through the nicknames that nobody is completely mono-culturally oriented, especially within the Nigerian context. In sum, they reflect what Du Bois calls 'double consciousness'. But, unlike Du Bois' notion of two thoughts, warring ideals and reconciled striving, these nicknames show that different ideals that are represented in them are well reconciled as can be seen especially in the form of the nicknames. In conclusion, we opine that the creative venture of the students as seen in the patterned creation of nicknames are utilised as a tool for reinventing their identities in a bid to engender a trendy and youth-friendly cultural paradigm.

\section{References}

Aboh, Romanus (2011): "Linguistic Constructions of Identity and Politics in Selected twentyfirst Century Nigerian Novels". Staff/Post Graduate seminar series, Department of English, University of Ibadan.

Adegbija, Efurosibina (1994): Language Attitude in Sub-Sahara Africa: a Sociolinguistic Overview. Frankfurt: Multilingual matters.

Adéoyè, Christopher L. (1972): Orúko Yorùbá. İbàdàn: Ìbàdàn University Press.

Adéoyè, Christopher L. (1979): Àsà àti İse Yorùbá. Ìbàdàn: Ìbàdàn University Press.

Ajileye, Mercy K. (1991): A Comparative Semantic Study of English and Yoruba Names. M.A Dissertation, Department of English, University of Ilorin.

Ajileye, Mercy K./Ajileye, Samuel S. (1997): "Pragmasociolinguistic Features of Yoruba Nicknames". In: Lawal, Bayo (ed.) (1997): Stylistics in Theory and Practice. Ilorin, Paragon Books: 195-204.

Akinnaso, Niyi F. (1980): "The Sociolinguistic Basis of Yoruba Personal Names". Anthropological Linguistics 22: 275-304

Atolagbe, Oluwadamilare D. (2011): A Morphosyntactic Study of Anglicised Yoruba Personal Names in selected secondary schools in Ibadan. M.A. dissertation, University of Ibadan.

Babalola, Adeboye/Alaba, Olugboyega (2003): A Dictionary of Yoruba Personal Names. Lagos, West African Book Publishers.

Bakhtin, Mikhail (1984): Rabelais and his world. Bloomington: Indiana University Press. 
Bakhtin, M. (1981): The Dialogic Imagination: four Essays. Austin: University of Texas Press.

Bakhtin, M. (1986): Speech Genres and other late Essays. Austin: University of Texas Press. Barthes, Roland (1957/1987): Mythologies. New York: Hill and Wang.

Bechar-Israeli, Haya (1995): "From 'Bonehead' to 'cLoNehEAd': Nicknames, Play and Identity on Internet Relay Chat". Journal of Computer-Mediated Communication 1.

Benwell, Bethan/Stokoe, Elizabeth (2006): Discourse and Identity. Edinburgh: Edinburgh University Press.

Cerulo, Karen A. (1997): "Identity Construction: New issues, New Directions". Annual Review of Sociology 23: 385-409.

Chandler, Daniel (2002): Semiotics: the basics. London: Routledge.

Dáramolá, Olú/Jéjé, Adébáyo (1967): Àwo, n Aṣà àti Òrị̣à Ile, Yorùbá. Ìbàdàn: Oníbon-Òjé Press/Book Industries.

Dimejesi, S. I. (2007): Onomastics in Igbo Language: a Syntactic and Semantic Approach. M.A. Dissertation, University of Ibadan.

Ecker, Robert (2011): "Creation of Internet Relay Chat Nicknames and their Usage in English Chatroom Discourse". Linguistik Online 50: 2-29.

Ekúndayò, Samuel A. (1977) "Restrictions on Personal Name sentences in the Yorùbá Noun

Phrase". African Linguistics 19: 55-77.

Evans, Gareth (1973): "The Causal Theory of Names". Proceedings of the Aristotelian Society. Supplementary Volumes 47: 187-208.

Faleye, Oladunjoye/Adegoju, Adeyemi (2012): "A Sociolinguistic Study of Deviant Orthographic Representation of Graduating Student's Names in a Nigerian University". Linguistik Online 53: 11-22.

Görlach, Manfred (2001): A dictionary of European anglicisms. Oxford, Oxford University Press.

Gottdiener, Mark (1995): Postmodern semiotics: material culture and the forms of postmodern life. Oxford and Cambridge, Blackwell.

Halliday, Michael (1978): Language as social semiotics. London, Arnold.

Harder, Kelsie (2008): "Names". In: Microsoft Encarta 2009 [DVD]. Redmond, WA: Microsoft Corporation.

Hodge, Robert/Kress, Gunter (1988): Social Semiotics. Cambridge: Polity Press.

Ikotun, Reuben O. (2013): "New Trends in Yoruba Personal Names among Yoruba Christians". Linguistik online 59: 65-83.

Katamba, Frances (1993): Morphology. London: Macmillan.

Knospe, Sebastian (2007): "English Meets German: on the Exploration of Anglicisms and Code-mixing in Press Language in the Context of the FIFA World Cup 2006". CamLing Proceedings 2007, Universität Greifswald: 138-145. http://www.ling.cam.ac.uk/camling/ Manuscripts/CamLing2007_Proceedings.pdf

Kripke, Saul (1972): "Naming and Necessity," and "Addenda." In: Davidson, D./Harman, C. (eds.) (1972): Semantics of Natural Language: 253-255; 763-769.

Lakaw, Alexander (2006): Hiding Behind Nicknames: a Linguistic Study of Anonymity in IRC chatrooms. Student thesis. Växjö University. http://nu.diva-portal.org/smash/record. jsf?pid=diva2:206935, accessed September 11, 2013. 
Malmkkjear, Kirsten (1995): The Linguistic Encyclopaedia. London: Routledge.

Manning, P. K. (1987): Semiotics and Fieldwork. Newbury Park, CA: Sage.

Martin, Bronwen/Ringham, Felizitas (2000): Dictionary of semiotics. London, Cassell.

McDowell, John H. (1981): "Towards a Semiotics of nicknaming: the Kamasá Example". Journal of American Folklore 94:1-18.

McKay, Tom (1981): "On Proper Names in Belief Ascriptions". Philosophical Studies: An International Journal for Philosophy in the Analytic Tradition 39: 287-303.

Morgan, Jane/O'Neill, Christopher/Harré, Rom (1979): Nicknames: Their Origins and Social

Consequences. London/Boston/Henley: Routledge \& Kegan Paul.

Odunjo, Joseph F. (1964): Kuye. Lagos: African Universities Press.

Òkédijí, Olú F. et al. (1971): "The Sociological Aspects of Traditional Yorùbá Names and

Titles". Odù 5: 64-79.

Oyeleye, Lekan (1982): The language of Achebe's Early Novels (in the context of Nigerian English): A study in Literary Stylistics. Ph.D. Thesis, University of Ife, Ile-Ife.

Odebode, Idowu (2005): "A Pragmasociolinguistic Study of Names and Nicknames in Soyinka's Death and the King's Horseman". In: Olateju, Moji/Oyeleye, Lekan. (eds.) (2005): Perspectives on Language and Literature. Ile-Ife, Obafemi Awolowo Press: 199214.

Peirce, Charles Sanders (1931): Collected papers. Cambridge: Harvard University Press.

Reid, Elizabeth M. (1991): Electropolis: Communication and Community on Internet Relay Chat. Honours Dissertation, University of Melbourne.

Rochberg-Halton, Eugene (1982): "Situation, Structure, and the Context of Meaning". The Sociological Quarterly 23: 455-476.

Sangotoro, T. K. (2002): The Grammar of Yoruba Personal Names. M.A. Dissertation, University of Ibadan.

Saussure, Ferdinand de (1983): Course in General Linguistics. London: Duckworth.

Saussure, Ferdinand de (1959): Course in General Linguistics. New York: McGraw-Hill.

Tajfel, Henri/Turner, John (1979): "An integrative Theory of Intergroup Conflict". In: Austin, William G./Worchel, Stephen (eds.) (1979): The Social Psychology of Intergroup Relations. Monterey, CA, Brooks/Cole: 33-47.

Turner, John C. (1985): "Social Categorization and the Self-Concept: A Social Cognitive Theory of Group Behavior". In: Lawler, Edward J. (ed.) (1985): Advances in Group Processes. Greenwich, CT, JAI: 77-121

Turner, John C. (1987): Rediscovering the Social Group: A Self-Categorization Theory. Oxford, Basil Blackwell.

Turner, John C. et al. (1994): "Self and Collective: Cognition and Social Context." Personality and Social Psychology Bulletin 20: 454-463.

Van Leeuwen, Theo (2005): Introducing social semiotics. London: Routledge.

Vannini, Phillip (2004): "Toward an interpretive analytics of the sign: interactionism, power, and semiosis". Studies in Symbolic Interaction, 27: 151-176.

Vannini, Phillip (2007): "Social Semiotics and Fieldwork: Method and Analytics". Qualitative Inquiry 13: 113-140.

Volosinov, Valentin (1973): Marxism and the philosophy of language. New York, Seminar Press. 